\title{
Prevalence of antibodies against Toxoplasma gondii and Neospora caninum in dogs
}

\author{
Helio Langoni, Felipe Fornazari, Rodrigo Costa da Silva, \\ Elis Talita Monti, Fausto Baptista Villa \\ Núcleo de Pesquisa em Zoonoses, Departamento de Higiene Veterinária e Saúde Pública, \\ Faculdade de Medicina Veterinária e Zootecnia, \\ Universidade Estadual Paulista "Júlio de Mesquita Filho", Botucatu, SP, Brazil.
}

Submitted: October 27, 2012; Approved: April 04, 2013.

\begin{abstract}
Toxoplasmosis and neosporosis are parasitic diseases of global importance. The present study had the objective to determine the influence of age, sex and breed in the prevalence of antibodies against both diseases in dogs from Brotas city, São Paulo State, Brazil. Blood samples of 342 dogs were collected, and the age, sex and breed of each animal were recorded. The serological diagnosis for toxoplasmosis and neosporosis were performed using the immunofluorescent antibody test (IFAT). The Fischer's test was used to calculate the association probability of the variables, with $\alpha=5 \%$. For toxoplasmosis the prevalence of antibodies was $26.9 \%$ (CI 95\% 22.4-31.8\%), and for neosporosis $4.97 \%$ (CI 95\% 3.1-7.8\%). The statistical analysis revealed a higher risk of infection for T. gondii in dogs with more than five years.
\end{abstract}

Key words: Toxoplasma gondii, Neospora caninum, IFAT.

Toxoplasma gondii is a worldwide distributed intracellular protozoan, able to infect several species of warmblooded animals. The infection is usually asymptomatic, but in some cases can cause severe illness and lead to death in both animals and humans. The three main routes of infection are: ingestion of oocysts excreted by cats, the definitive host; ingestion of tissues of an infected animal; and vertical transmission (Dubey, 2007). Neospora caninum is a parasite similar to T.gondii in various aspects, also affecting several species of animals, causing abortion, neurological disorders and death (Dubey and Lindsay, 1996; Reichel et al., 2007). The dog has an important role in the life cycle of N. caninum, acting as the definitive host (Lindsay, 1999), and eliminating the oocysts in their feces. The routes of infection are the same of T.gondii. Thus, the prevalence of infection of N. caninum in dogs is related to the environmental contamination by oocysts.

Previous studies have demonstrated a wide prevalence of antibodies against both parasites in several locations of Brazil, usually up to $10.0 \%$ (Cañón-Franco et al., 2003; Meireles et al., 2004; Andreotti et al., 2006; Collantes-Fernández et al., 2008; Figueredo et al., 2008; Frid-
lund-Plugge et al., 2008; Locatelli-Dittrich et al., 2008; Benetti et al., 2009; Guimarães et al., 2009; Silva et al., 2010; Valadas et al., 2010). In most of these studies the prevalence for $T$. gondii antibodies are higher than for $N$. caninum, indicating a higher exposure of dogs by this parasite. Some risk factors have been observed in dogs, such as the increasing infection rate according to age, and in animals with access to street, for both $T$. gondii and $N$. caninum (Cabral et al., 1998; Brito et al., 2002; Gennari et al., 2002; Barbosa et al., 2003; Cañón-Franco et al., 2004; Cunha-Filho et al., 2004; Fernandes et al., 2004; Azevedo et al., 2005). The aim of the present study was to determine the influence of age, sex and breed in the prevalence of antibodies against $T$. gondii and $N$. caninum in dogs.

Blood samples of 342 dogs were collected in the city

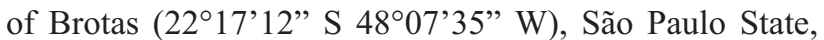
Brazil, from May 2005 to May 2006, and from February to May of 2009. The number of samples of each year was 189 , 80 and 73, in 2005, 2006 and 2009, respectively. The animals were chosen randomly, and were from a campaign of responsible ownership of dogs, realized by local autorities. The age, sex and breed of each animal were recorded.

Send correspondence to H. Langoni. Zoonosis Research Nucleus, Department of Veterinary Hygiene and Public Health, School of Veterinary Medicine and Animal Science, Universidade Estadual Paulista "Júlio de Mesquita Filho”, 18618-970 Botucatu, SP, Brazil. E-mail: hlangoni@fmvz.unesp.br. 
The exams were realized in the Zoonosis Research Nucleus (NUPEZO), UNESP, Botucatu city. For both toxoplasmosis and neosporosis diagnosis, the immunofluorescent antibody test (IFAT) was performed. Positive and negative controls were used. For toxoplasmosis, the sera was initially tested in the dilution $1: 16$, and samples that showed positive results were further tested in four-fold dilutions until its final titer. For neosporosis the initial dilution was 1:25, and positive samples were further tested in two-fold dilutions. The cut-off titer for toxoplasmosis was 16 , and for neosporosis 25 . The Fischer's test was used to calculate the association probability of the variables, with $\alpha=5 \%$.

Of the 342 animals, 65 had less than one year, 208 between one and five years, and 69 more than five years. Regarding to sex, 289 were females and 53 were males. Most of the animals were crossbreed $(\mathrm{n}=295)$, while the minority were pure breed $(\mathrm{n}=47)$. The prevalence of infection by T. gondii was $26.9 \%(92 / 342$; CI 95\% 22.4-31.8\%), with titers $16(\mathrm{n}=59), 64(\mathrm{n}=28), 256(\mathrm{n}=4)$ and $1024(\mathrm{n}=1)$. The prevalence of infection by $N$. caninum was $4.9 \%$ $(17 / 342$; CI $95 \% 3.1-7.8 \%)$, with titers $25(\mathrm{n}=2), 50$ $(\mathrm{n}=8), 100(\mathrm{n}=2)$ and $200(\mathrm{n}=2)$. Eight animals had positive results for both parasites. The only statistical difference observed in the variables studied was that dogs with more than five years old had greater risk to get infected by $T$. gondii, when compared with younger dogs. The results are summarized in Tables 1 and 2.

The high prevalence of antibodies against $T$. gondii confirms previous studies performed in Brazil, demonstrating the wide distribution of the parasite in the animal population, especially dogs. As we observed in the present study, older animals have greater risk to get infected by $T$. gondii, (Brito et al., 2002; Cañón-Franco et al., 2004; Azevedo et al., 2005; Silva et al., 2010) due to the chronic pattern of the disease, which increases the chances of infection during the life time. The breed and sex did not show significant differences of infection, as observed by others authors (Cabral et al., 1998; Ali et al., 2003; Azevedo et al., 2005).

The low prevalence of antibodies against $N$. caninum in dogs is also in accordance with previous studies. However, because the dog is the definitive host, it can eliminate thousands of oocysts in the environment. Thus, environmental contamination by $N$. caninum can be considerable. As observed by other authors (Cheadle et al., 1999; Ferroglio et al., 2007; Collantes-Fernández et al., 2008), the sex does not influence the infection by N.caninum. In relation to age, no statistical difference was observed. However, that disagree with other studies (Wouda et al., 1999; Fernandes et al., 2004; Ferroglio et al., 2007), where older animals presented a greater risk to get infected, probably by

Table 1 - Statistical association between the studied variables and serological results to Neospora caninum in dogs from Brotas, São Paulo State, Brazil.

\begin{tabular}{llccccc}
\hline Variable & & $\mathrm{N}^{\mathrm{a}}$ & IFAT $^{\mathrm{b}}$ & Percentage; IC95 $^{\mathrm{c}}$ & OR (IC95) $^{\mathrm{d}}$ & $\mathrm{p}^{\mathrm{e}}$ \\
\hline \multirow{2}{*}{ Sex } & Male & 53 & 2 & $3.8 ; 1.2-12.7$ & $1.4(0.3-6.3)$ & 0.49 \\
& Female & 289 & 15 & $5.2 ; 3.2-8.4$ & & \\
\multirow{2}{*}{ Age (years) } & $<1$ & 65 & 2 & $3.1 ; 0.9-10.5$ & - & 0.73 \\
& $1.1-5$ & 208 & 11 & $5.3 ; 3.0-9.2$ & & \\
& $>5.1$ & 69 & 4 & $5.8 ; 2.4-14.9$ & & \\
\multirow{2}{*}{ Breed } & Crossbreed & 295 & 15 & $5.1 ; 3.1-8.2$ & $0.8(0.2-3.8)$ & 0.58 \\
& Pure & 47 & 2 & $4.2 ; 1.3-14.2$ & & \\
\hline
\end{tabular}

${ }^{a} \mathrm{~N}$ : number of animals tested. ${ }^{\mathrm{b}}$ IFAT: imunofluorescent antibody test. ${ }^{\mathrm{c}}$ Frequency of positive animals based in the variable $($ confidence interval $=95 \%)$. ${ }^{\mathrm{d}}$ OR: Odds ratio (confidence interval $=95 \%$ ). ${ }^{\mathrm{e}} \mathrm{p}$ : $\mathrm{p}$ value to $\alpha=0.05$.

Table 2 - Statistical association between the studied variables and serological results to Toxoplasma gondii in dogs from Brotas, São Paulo State, Brazil.

\begin{tabular}{llccccc}
\hline Variable & & $\mathrm{N}^{\mathrm{a}}$ & IFAT $^{\mathrm{b}}$ & Percentage; IC95 $^{\mathrm{c}}$ & OR (IC95) $^{\mathrm{d}}$ & $\mathrm{p}^{\mathrm{e}}$ \\
\hline Sex & Male & 53 & 14 & $26.4 ; 16.5-39.6$ & $1.0(0.5-2.0)$ & 0.54 \\
& Female & 289 & 78 & $27.0 ; 22.2-32.4$ & & \\
\multirow{2}{*}{ Age (years) } & $<1$ & 65 & 5 & $7.7 ; 3.4-16.8$ & - & 0.00 \\
& $1.1-5$ & 208 & 61 & $29.3 ; 23.6-35.9$ & & \\
& $>5.1$ & 69 & 26 & $37.7 ; 27.2-49.5$ & & 0.13 \\
\multirow{2}{*}{ Breed } & Crossbreed & 295 & 83 & $28.1 ; 23.3-33.5$ & $0.6(0.3-1.3)$ & \\
& Pure & 47 & 9 & $19.1 ; 10.5-32.6$ & & \\
\hline
\end{tabular}

${ }^{a} \mathrm{~N}$ : number of animals tested. ${ }^{b}$ IFAT: imunofluorescent antibody test. ${ }^{c}$ Frequency of positive animals based in the variable $($ confidence interval $=95 \%)$. ${ }^{\mathrm{d}}$ OR: Odds ratio (confidence interval $=95 \%$ ). ${ }^{\mathrm{e}} \mathrm{p}$ : $\mathrm{p}$ value to $\alpha=0.05$. 
the same reasons that $T$. gondii. We did not observe statistical difference related to breed. Capelli et al. (2004) detected a higher prevalence in pure breed dogs, and suggested a genetic factor that predispose to infection, or a more efficient vertical transmission. Collantes-Fernadez et al. (2008) found a higher prevalence in crossbreed dogs, but affirmed that this result was probably biased to the large sample size. Fernandes et al. (2004) found similar results. The role of breeds in the epidemiology of canine neosporosis is not well established.

The present study shows that dogs from Brotas city are widely infected by $T$. gondii and $N$. caninum, corroborating previous studies realized in other Brazilian cities. Dogs with more than five years have greater risk of get infected by $T$. gondii. The sex appears not to influence in the infection by both parasites. More studies are needed to understand the role of different breeds in the pattern of infection by $N$. caninum.

\section{References}

Ali CN, Harris JA, Watkins JD, Adesiyun AA (2003) Seroepidemiology of Toxoplasma gondii in dogs in Trinidad and Tobago. Vet Parasitol 113:179-187.

Andreotti R, Oliveira JM, Silva EA, Oshiro LM, Matos MFC (2006) Occurrence of Neospora caninum in dogs and its correlation with visceral leishmaniasis in the urban area of Campo Grande, Mato Grosso do Sul, Brazil. Vet Parasitol 135:375-379.

Azevedo SS, Batista CSA, Vasconcellos SA, Aguiar DM, Ragozo AMA, Rodrigues AAR, Alves CJ, Gennari SM (2005) Seroepidemiology of Toxoplasma gondii and Neospora caninum in dogs from the state of Paraíba, Northeast region of Brazil. Res Vet Sci 79:51-56.

Barbosa MVF, Guimarães JE, Almeida MAO, Gondim LFP, Regis GB (2003) Frequência de anticorpos IgG antiToxoplasma gondii em soros de cães errantes da cidade de SalvadorBa, hia, Brasil. Braz J Vet Res Anim Sci 40:457465.

Benetti AH, Schein FB, Santos TR, Toniollo GH, Costa AJ, Mineo JR, Lobato J, Silva DAO, Gennari SM (2009) Pesquisa de anticorpos anti-Neospora caninum em bovinos leiteiros, cães e trabalhadores rurais da região Sudoeste do Estado de Mato Grosso. Brazil J Vet Parasitol 18:29-33.

Brito AF, de Souza LC, Silva AV, Langoni H (2002) Epidemiological and serological aspects in canine toxoplasmosis in animals with nervous symptoms. Mem Inst Oswaldo Cruz 97:31-35.

Cabral DD, Silva DAO, Mineo JR, Ferreira FA, Duran FP (1998) Frequency of anti-Toxoplasma gondii antibodies in apparently healthy dogs in the city of Uberlândia-MG. Brazil J Vet Parasitol 7:87-90.

Cañón-Franco WA, Bergamaschi DP, Labruna MB, Camargo LMA, Silva JCR, Pinter A, Gennari SM (2004) Occurrence of anti-Toxoplasma gondii antibodies in dogs in the urban area of Monte Negro, Rondônia, Brazil. Vet Res Commun 28:113-118.

Cañón-Franco WA, Bergamaschi DP, Labruna MB, Camargo LMA, Souza SLP, Silva JCR, Pinter A, Dubey JP, Gennari
SM (2003) Prevalence of antibodies to Neospora caninum in dogs from Amazon, Brazil. Vet Parasitol 115:71-74.

Capelli G, Nardelli S, Di Regalbono AF, Scalac A, Pietrobelli M (2004) Sero-epidemiological survey of Neospora caninum infection in dogs in north-eastern Italy. Vet Parasitol 123:143-148.

Cheadle MA, Lindsay DS, Blagburn BL (1999) Prevalence of antibodies to Neospora caninum in dogs. Vet Parasitol 85:325-330.

Coiro CJ, Langoni H, Silva RC, Ullmann LS (2011) Fatores de risco para leptospirose, leishmaniose, neosporose e toxoplasmose em cães domiciliados e peridomiciliados em Botucatu, SP. Vet Zootec 18:384-392.

Collantes-Fernández E, Gómez-Bautista M, Miró G, ÁlvarezGarcía G, Pereira-Bueno J, Frisuelos C, Ortega-Mora LM (2008) Seroprevalence and risk factors associated with Neospora caninum infection in different dog populations in Spain. Vet Parasitol 152:148-151.

Cunha-Filho N.A, Lucas AS, Pappen FG, Ragozo AMA, Gennari SM, Junior TL, Farias NAR (2008) Fatores de risco e prevalência de anticorpos anti-Neospora caninum em cães urbanos e rurais do Rio grande do Sul, Brasil. Brazil. J Vet Parasitol 17:301-306.

Dubey JP, Lindsay DS (1996) A review of Neospora caninum and neosporosis. Vet Parasitol 67:1-59.

Dubey JP (2007) The history and life cycle of Toxoplasma gondii. In: Weiss, L.M., Kim, K. (eds), Toxoplasma gondii: the model apicomplexan - perspectives and methods. Hardbound: Elsevier Ltd, 1-17.

Fernandes BCTM, Gennari SM, Souza SLP, Carvalho JM, Oliveira WG, Cury MC (2004) Prevalence of anti-Neospora caninum antibodies in dogs from urban, periurban and rural areas of the city of Uberlândia, Minas Gerais, Brazil. Vet Parasitol 123:33-40.

Ferroglio E, Pasino M, Ronco F, Benà A, Trisciuoglio A (2007) Seroprevalence of antibodies to Neospora caninum in urban and rural dogs in north-west Italy. Zoonoses Public Health $54: 135-139$

Figueredo L.A, Dantas-Torres F, de Faria EB, Gondim LFP, Simões-Mattos L, Brandão-Filho SP, Mota RA (2008) Occurrence of antibodies to Neospora caninum and Toxoplasma gondii in dogs from Pernambuco, Northeast Brazil. Vet Parasitol 157:9-13.

Fridlund-Plugge N, Montiani-Ferreira F, Richartz RRTB, Pizzol JD, Machado Jr PC, Patrício, LFL, Rosinelli AS, LocatelliDittrich R (2008) Frequency of antibodies against Neospora caninum in stray and domiciled dogs from urban, periurban and rural areas from Paraná State, Southern Brazil. Brazil J Vet Parasitol 17:222-226.

Gennari SM, Yai LE, Dáuria SNR, Cardoso SMS, Kwok OCH, Jenkins MC, Dubey JP (2002) Occurence of Neospora caninum antibodies in sera from dogs of the city of São Paulo, Brazil. Vet Parasitol 106:177-179.

Guimarães AM, Rocha CM, Oliveira TM, Rosado IR, Morais LG, Santos RR (2009) Factors associated the seropositivity for Babesia, Toxoplasma, Neospora and Leishmania in dogs attended at nine veterinary clinics in the municipality of Lavras, MG. Brazil J Vet Parasitol 18:49-53.

Lindsay DS, Dubey JP, Ducan RB (1999) Confirmation that the dog is a definitive host for Neospora caninum. Vet Parasitol 82:327-333. 
Locatelli-Dittrich R, Machado Jr PC, Fridlund-Plugge N, Richartz RRTB, Montiani-Ferreira F, Patrício LFL, Patrício MAC, Joineau MG, Pieppe M (2008) Determination and correlation of anti-Neospora caninum antibodies in cattle and dogs from Paraná, Brazil. Brazil J Vet Parasitol 17:191-196.

Meireles LR, Galisteo AJJ, Pompeu E, Andrade HFJ (2004) Toxoplasma gondii spreading in an urban area evaluated by seroprevalence in free-living cats and dogs. Trop Med Int Health 9:876-881.

Reichel MP, Ellis JT, Dubey JP (2007) Neosporosis and hammondiosis in dogs. J Small Anim Pract 48:308-312.

Silva RC, Lima VY, Tanaka EM, Silva AV, Souza LC, Langoni H (2010) Risk factors and presence of antibodies to
Toxopalsma gondii in dogs from the coast of São Paulo State, Brazil. Pesq Vet Bras 30:161-166.

Valadas S, Minervino AH, Lima VM, Soares RM, Ortolani EL, Gennari SM (2010) Occurrence of antibodies antiNeospora-caninum, anti-Toxoplasma gondii, and antiLeishmania chagasi in serum of dogs from Pará State, Amazon, Brazil. Parasitol Res 107:453-457.

Wouda W, Dijkstra Th, Kramer AMH, Van Maanen C, Brinkhof JMA (1999) Seroepidemiological evidence for a relationship between Neospora caninum infections in dogs and cattle. Int J Parasitol 29:1677-1682.

All the content of the journal, except where otherwise noted, is licensed under a Creative Commons License CC BY-NC. 